\title{
Severe mental retardation in six generations of a large South African family carrying a translocation $\mathrm{t}(6 ; 10)(\mathrm{q} 27 ; \mathrm{q} 25 \cdot 2)$
}

\author{
J BRUSNICKY, K M M VAN HEERDEN, G DE JONG, A S CRONJÉ, \\ AND A E RETIEF \\ From the MRC Research Unit for Cytogenetics, Medical School, University of Stellenbosch, PO Box 63, \\ Tygerberg, Republic of South Africa.
}

SUMmaRY Partial monosomy $10 \mathrm{q} 25 \cdot 2 \rightarrow$ qter, detected in a newborn baby with multiple congenital abnormalities, was found to be derived from a balanced maternal translocation $t(6 ; 10)(q 27 ; q 25 \cdot 2)$. The pedigree of six generations of the family is presented. In an extensive cytogenetic study of this family, the chromosome complements of 57 subjects, potentially capable of carrying some form of this translocation, were analysed. A total of 14 male carriers (four obligatory) and 14 female carriers (three obligatory) of this translocation was found. Partial trisomy $10 \mathrm{q} 25 \cdot 2 \rightarrow$ qter, associated with severe mental retardation, occurred in nine cases, eight males and one female. Two of these eight males were detected prenatally and subsequently therapeutically aborted. The phenotypes of the family members with partial trisomy $10 \mathrm{q} 25 \cdot 2 \rightarrow$ qter are compared to each other and to those reported in publications. No further cases of partial monosomy $10 \mathrm{q} 25 \cdot 2 \rightarrow$ qter were encountered. A review of published reports of partial monosomy and partial trisomy 10 qter is given. The apparent absence of infertility, the occurrence of many first trimester miscarriages, and the marked sex ratio are discussed.

The application of improved culture and staining techniques has enabled the study of longer chromosomes and, consequently, very small aberrations in the detailed banding pattern of each chromosome can be more easily detected. As partial monosomy and partial trisomy of specific regions of the chromosomes are associated with characteristic phenotypic abnormalities, an accurate determination of the breakpoints facilitates the classification of new clinical syndromes.

Francke $^{1}$ recorded the first case of partial trisomy for the distal two-thirds of the long arm of chromosome 10 in a female baby whose mother was found to carry a balanced translocation $t(10 ; 15)$. Partial trisomy for the distal third of the long arm $(10 \mathrm{q} 22 \rightarrow \mathrm{qter})$ was first reported by Laurent $e t a l^{2}$ in a female baby and also in her male first cousin. A balanced familial translocation $\mathrm{t}(1 ; 10)(\mathrm{q} 44 ; \mathrm{q} 22)$ was traced back to their maternal grandfather. Yunis and Sanche $z^{3}$ proposed that the specific phenotype of their patient, who was partially trisomic for $10 \mathrm{q} 24 \rightarrow \mathrm{qter}$, be recognised as a new syndrome.

Received for publication 26 July 1985.

Accepted for publication 12 August 1985
Subsequently there have been published reports of partial trisomy $10 \mathrm{q} 22 \rightarrow \mathrm{qter},{ }^{4}$ partial trisomy $10 \mathrm{q} 23 \rightarrow \mathrm{qter}^{5}$ partial trisomy $10 \mathrm{q} 24 \rightarrow \mathrm{qter}^{6},{ }^{6-18}$ partial trisomy $10 \mathrm{q} 24 \cdot 2 \rightarrow \mathrm{q} 25 \cdot 3,{ }^{19}$ and partial trisomy $10 \mathrm{q} 25 \rightarrow$ qter.

The partial trisomy $10 \mathrm{q}$ syndrome has been delineated by $\mathrm{Smith}^{22}$ as trisomy for $10 \mathrm{q} 24 \rightarrow$ qter. Both pre- and postnatal growth retardation occurred in the majority of cases. The characteristic phenotype has unique craniofacial features, including microcephaly, a flat face with a large forehead and high arched eyebrows, short palpebral fissures, microphthalmia, a broad and depressed nasal bridge, a bow shaped mouth with prominent upper lip, cleft palate, and malformed, posteriorly rotated ears. Limb, heart, and renal malformations, in addition to severe mental retardation, cause many such subjects to be bedridden and unable to communicate.

The clinical characteristics of partial trisomy $10 \mathrm{q} 24 \rightarrow$ qter and partial trisomy $10 \mathrm{q} 25 \rightarrow$ qter have more recently been separately described by Schinzel, ${ }^{23}$ after reviewing 24 and 11 cases respectively. It appears that subjects in the latter group, although also severely mentally retarded, have a 
comparatively normal birth weight and lack major heart, renal, and palatal malformations and can thus survive to an adult age.

It has, however, not yet been possible to delineate a syndrome for partial monosomy $10 \mathrm{q}$, as a constant phenotype has still not emerged from the nine reported cases described. Partial monosomy $10 \mathrm{q} 23 \rightarrow$ qter, ${ }^{24}$ partial monosomy $10 \mathrm{q} 25 \rightarrow \mathrm{qter},{ }^{25-27}$ and partial monosomy $10 \mathrm{q} 26 \rightarrow \mathrm{qter}^{28-32}$ have been reported.

In the large pedigree presented in this article, the region $10 \mathrm{q} 25 \cdot 2 \rightarrow \mathrm{qter}$ has been found to be partially trisomic in nine subjects. The clinical features of six of these are presented and compared. This region was found to be partially monosomic in only one case, the proband.

\section{Case report of the proband}

The index patient was referred for multiple congenital abnormalities and indeterminate sex. The baby was born by Caesarian section at 36 weeks' gestation because of breech presentation. At the time of birth, the healthy and unrelated father and mother were 25 and 23 years old respectively. The mother had had one previous pregnancy which ended spontaneously in a first trimester miscarriage.

The birth weight was $2440 \mathrm{~g}$ and the head circumference was $32 \mathrm{~cm}$. Asphyxia neonatorum was present. The baby had scaphocephaly and a small anterior fontanelle. Examination revealed a wide, prominent nose bridge, a slight upward slant of the lateral canthi, a highly arched palate, micrognathia, low set, big, abnormally shaped ears, and a short broad neck (fig 1). The nipples were widely spaced. A cardiac murmur and signs of respiratory distress were present. The hands were broad with low placed thumbs and long, broad fingers. The hands were held in flexion and ulnar deviation. There was bilateral clinodactyly. A simian crease was present on the right palm. The lower limb abnormalities included talipes calcaneovarus and congenital hip dislocation. The urogenital tract showed labioscrotal folds, a phallus, perineal hypospadias, and an anteriorly displaced anal opening.

The patient died 15 days after birth. Necropsy findings confirmed the presence of a heart defect, a small ventricular septal defect. The gonads, found intra-abdominally, were a normal testis in the left internal inguinal aperture and a small nodule of testicular tissue in the right pelvic area. A small structure, possibly a rudimentary uterus, was found posterior to the bladder. This was histologically identified as fibromuscular tissue with tubules of undefined origin. Only one ectopic, dysplastic kidney was present; this was situated on the right side of the pelvis.

\section{Cytogenetic analysis of the family}

Standard procedures were used for the cultivation of blood lymphocytes, skin fibroblasts, gonadal tissue, and amniotic fluid. Methotrexate was used to improve the quality and length of the chromosomes in the lymphocyte cultures. The chromosomal DNA was denatured by trypsin or heat or both and subsequently stained with Giemsa ${ }^{33}$ or quinacrine ${ }^{34}$ stains. Banding analysis and breakpoint determination were done according to the Paris Conference ${ }^{35}$ and the ISCN. ${ }^{36}$

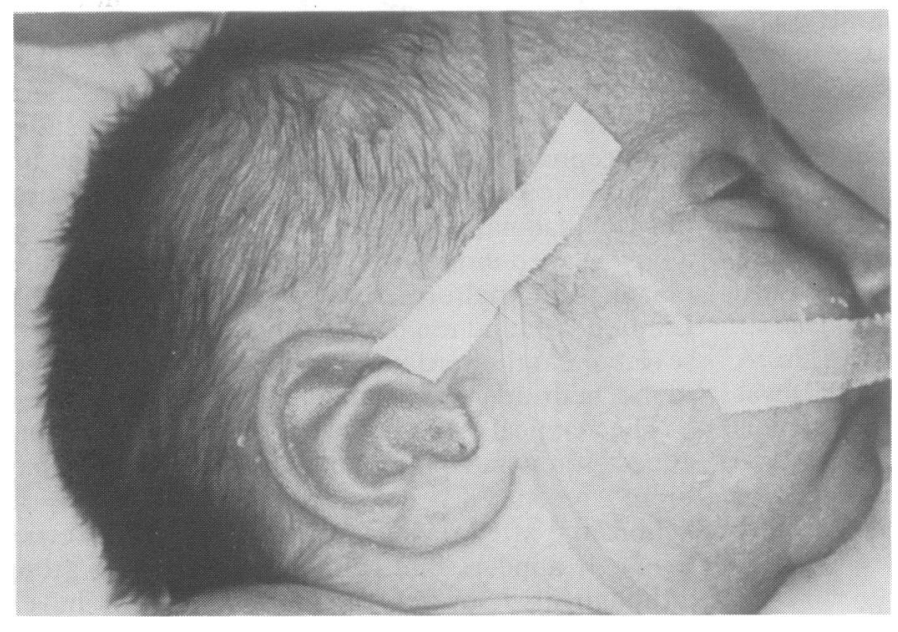

FIG 1 Proband (V.35) at birth. 


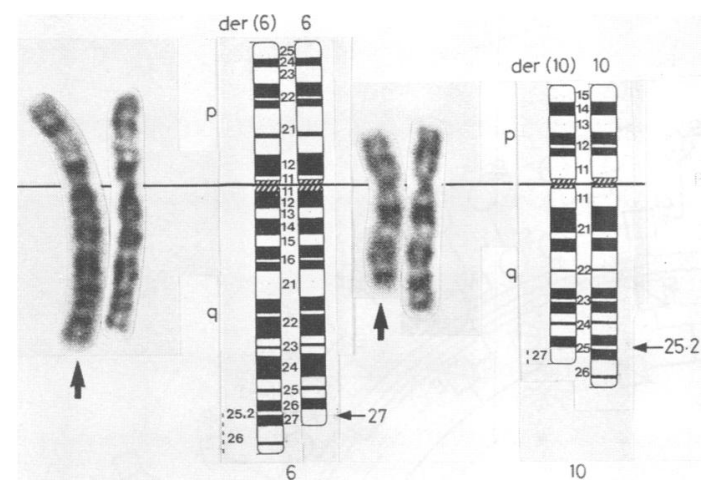

FIG $2 G$ banded chromosomes 6 and 10 involved in the familial reciprocal translocation $t(6 ; 10)(q 27 ; q 25 \cdot 2)$. Large arrows indicate derivative chromosomes. Small arrows indicate breakpoints on the diagrammatic representations of these chromosomes.

In the proband, a $46, X Y, \operatorname{der}(10), t(6 ; 10)(q 27 ; 25 \cdot 2)$ chromosome complement (breakpoints shown in fig 2) was found in the lymphocytes and in the left gonad. The chromosome analysis of the mother of the proband revealed a balanced reciprocal translocation (breakpoints shown in fig 2): $46, X X, t(6 ; 10)(q 27 ; q 25 \cdot 2)$. The father's karyotype was normal.

The large pedigree, including six generations of this family, is presented in fig 3 . The results of the chromosome analyses of 56 family members are given in table 1 . The proband was the only case with

TABLE 1 Chromosome analysis of the pedigree.

\begin{tabular}{|c|c|c|}
\hline Chromosome complement & No of cases & Pedigree No \\
\hline $46, X Y$ & 11 & $\begin{array}{l}\text { III.13-14, III.20, } \\
\text { IV.19-21, IV.65, } \\
\text { IV.69, IV.71, V.3, VI.4 }\end{array}$ \\
\hline $46, \mathrm{XX}$ & 15 & $\begin{array}{l}\text { III.4, III.19, IV.5, } \\
\text { IV.24-25, IV. } 60-64 \text {, } \\
\text { IV. } 66, \text { V. } 20, \text { V. } 26, \text { V.30, } \\
\text { V.38, VI.1 }\end{array}$ \\
\hline $46, X Y, t(6 ; 10)(q 27 ; q 25 \cdot 2)$ & 10 & $\begin{array}{l}\text { III. } 23 \text {, III. } 30-31, \text { IV. } 10 \text {, } \\
\text { IV.54, IV. } 58 \text {, IV. } 72-73 \text {, } \\
\text { V. } 2, \text { V. } 23\end{array}$ \\
\hline $46, X X, t(6 ; 10)(q 27 ; q 25 \cdot 2)$ & 11 & $\begin{array}{l}\text { IV.1, IV.57, IV.59, } \\
\text { IV.67-68, IV.70, V.1, } \\
\text { V.18-19, V.31, VI.2 }\end{array}$ \\
\hline $46, X Y, \operatorname{der}(6), t(6 ; 10)(q 27 ; q 25 \cdot 2)$ & 7 & $\begin{array}{l}\text { IV.56, V.17, V.22, V.27, } \\
\text { V.36-37, VI.3 }\end{array}$ \\
\hline $46, \mathrm{XX}, \operatorname{der}(6), \mathrm{t}(6 ; 10)(\mathrm{q} 27 ; \mathrm{q} 25 \cdot 2)$ & 1 & $V .21$ \\
\hline $46, X Y, \operatorname{der}(10), t(6 ; 10)(q 27 ; q 25 \cdot 2)$ & 1 & V. 35 \\
\hline Total & 56 & \\
\hline
\end{tabular}

partial monosomy $10 \mathrm{q} 25 \cdot 2 \rightarrow$ qter. Two (table 1 , V.36 and V.37) of the eight cases of partial trisomy $10 \mathrm{q} 25 \cdot 2 \rightarrow$ qter were found prenatally in two subsequent pregnancies of the mother of the proband; these pregnancies were both terminated at 20 weeks. A balanced translocation $\mathrm{t}(6 ; 10)(\mathrm{q} 27 ; \mathrm{q} 25 \cdot 2)$ was found in 21 subjects ( 10 males and 11 females); another seven deceased persons (table 1, I.5, II.1, II.10, III.1, III.5, III.21, and IV.11) were assumed to be obligate carriers. Twenty-six subjects had a normal karyotype: 11 were $46, X Y$ and 15 were $46, X X$.

Table 2 shows the chromosome complement of the offspring of 21 carriers. Of the 53 phenotypically normal persons born to male and female carriers, 27 had a balanced karyotype and 26 had normal chromosomes. In the group where the father was the carrier, it was found that $50 \%$ of the offspring had a balanced karyotype and $35 \%$ of the offspring had a normal karyotype. In the group where the mother was the carrier, these values were $28 \%$ and $48 \%$, respectively. In the group of 12 phenotypically abnormal subjects, there was one case of partial monosomy $10 \mathrm{q} 25 \cdot 2 \rightarrow \mathrm{qter}$, nine cases of partial trisomy $10 \mathrm{q} 25 \cdot 2 \rightarrow \mathrm{qter}$, and two congenitally abnormal females, who died neonatally before the initiation of this study. An institutionalised male (fig 3 , III.29), born with the phenotypic features of partial trisomy $10 \mathrm{q}$, died without a cytogenetic evaluation; he has been included in the above nine cases. A child with partial trisomy $10 \mathrm{q}$ was born to four of the 11 carrier fathers and to three of the 10 carrier mothers; a fourth carrier mother (the mother of the proband) had two such pregnancies teminated. The number of miscarriages recorded for male and female carriers was similar, 10 and nine respectively; a reliable figure could not be accurately assessed for the earlier generations.

Male carriers had 24 male and 16 female children. Female carriers had 15 male and 10 female children. It is interesting to note that, in each case, the male to female ratio is $3: 2$. The significance thereof will be dealt with in the discussion.

An amniocentesis was carried out in seven cases where one of the parents was a carrier of the $t(6 ; 10)(q 27 ; q 25 \cdot 2)$ translocation. The results of the chromosome analyses of the amniotic fluids are as follows: three normal females (V.30, V.38, and VI.1), two carrier females (V.31 and VI.2), and two males with partial trisomy $10 \mathrm{q}$ (V.36 and V.37). These findings were confirmed in the skin fibroblasts of the fetus after a therapeutic termination in the last two cases, and in the blood lymphocytes after birth in three of the first five cases. The recently evaluated pregnancies V.38 and VI.2 have not yet reached term; follow up studies will be carried out postnatally. 


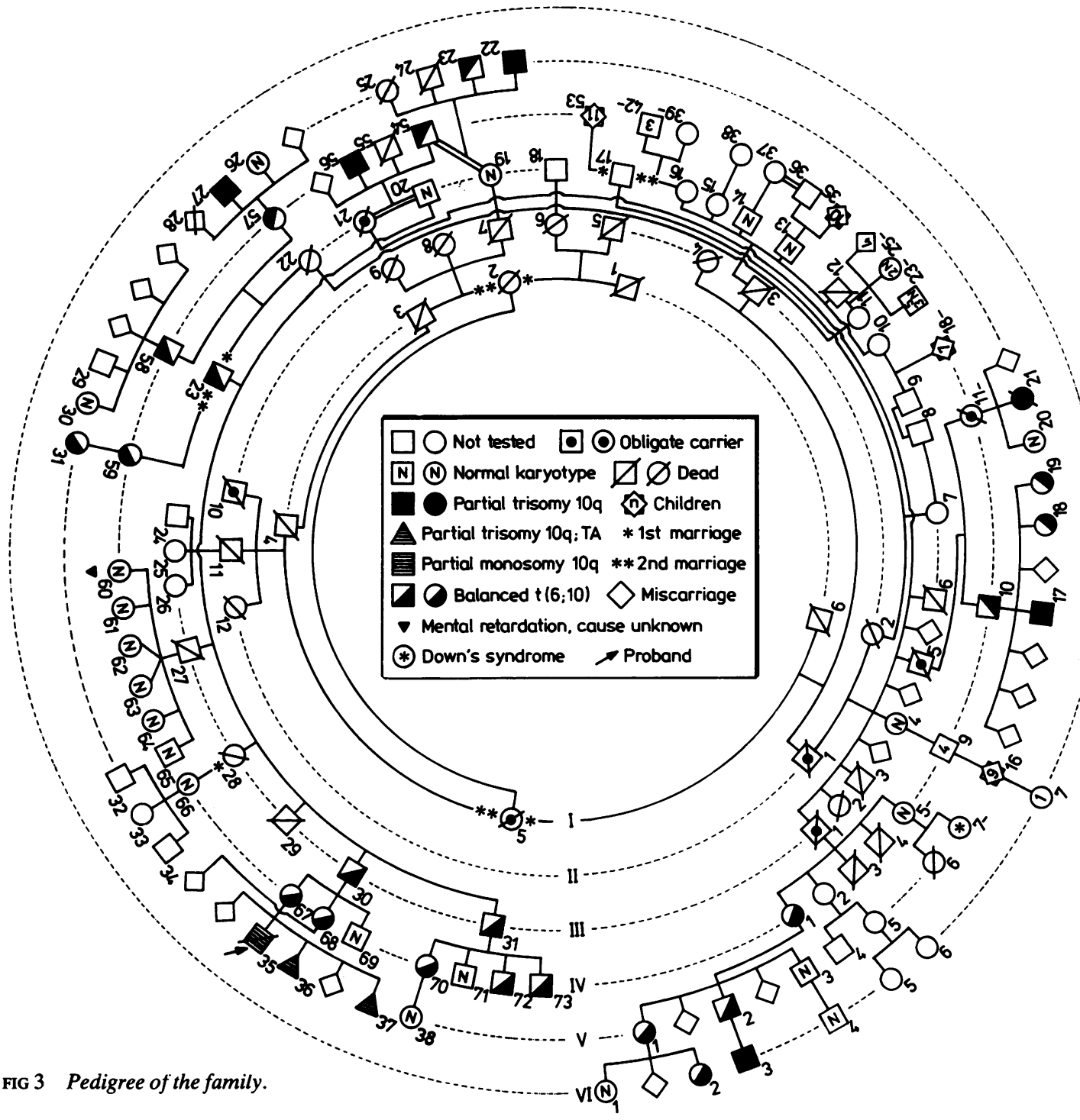

TABLE 2 Chromosome complement of the offspring of the carriers.

\begin{tabular}{|c|c|c|c|c|c|c|}
\hline \multirow[t]{2}{*}{ Karyotype } & \multicolumn{2}{|c|}{ Offspring of 11 male carriers } & \multicolumn{2}{|c|}{ Offspring of 10 female carriers } & \multirow[t]{2}{*}{ Totals } & \\
\hline & $46, X Y$ & $46, X X$ & $46, X Y$ & $46, X X$ & & \\
\hline Normal & 10 & 4 & 6 & 6 & 26 & 53 \\
\hline Balanced & 10 & 10 & 4 & 3 & 27 & \\
\hline $\begin{array}{l}\text { Partial trisomy } 10 \mathrm{q} \\
\text { Partial monosomy } 10 \mathrm{q} \\
\text { Congenital abnormality: not identified }\end{array}$ & 4 & 2 & $\begin{array}{l}4 \\
1\end{array}$ & 1 & $\begin{array}{l}9 \\
1 \\
2\end{array}$ & 12 \\
\hline Miscarriages & & & & & & \\
\hline
\end{tabular}


Case reports of family members with partial trisomy 10q

CASE 1

IV.56 is the third child of normal, consanguineous parents. After an uneventful pregnancy, he was born at term by normal vertex delivery. His birth weight is unknown. His father and his mother were 38 and 37 years old, respectively, at the time of his birth.

When he was evaluated for the first time at the age of 33 years, he presented with the following clinical features (fig 4): normal weight $(57 \mathrm{~kg})$, growth retardation (height $160 \mathrm{~cm}$ ), severe mental retardation, a relatively large head (head circumference $55 \mathrm{~cm}$ ), brachycephaly, a large high forehead, long facies, narrow palpebral fissures, mongoloid slanting eyes, hypertelorism (inner canthal measurement $4 \mathrm{~cm}$, outer canthal measurement $11 \mathrm{~cm}$ ), a prominent nasal bridge, prognathism, large ears, drooping shoulders, severe kyphoscoliosis, thoracic dysplasia, long thin fingers, and a valgus deformity of the feet. Since the age of 30 years, he has become progressively deaf.

\section{CASE 2}

V.22 is the oldest child of normal, consanguineous parents. After an uneventful pregnancy, he was born at term by normal vertex delivery; the birth weight was $3100 \mathrm{~g}$. His father and mother were 22 and 21 years old, respectively, at the time of his birth.

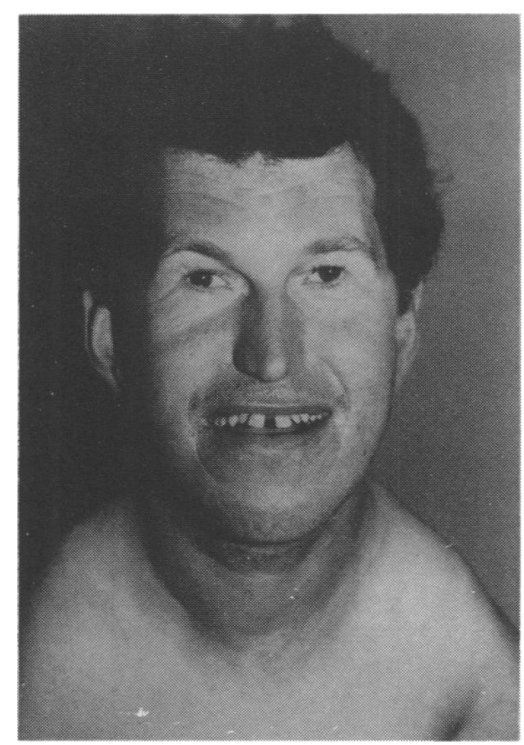

FIG 4 Case 1 (IV.56) at the age of 33 years.
At the age of 19 years he presented with the following features (fig 5): weight $44 \mathrm{~kg}$, growth retardation (height $157 \mathrm{~cm}$ ), severe mental retardation, a relatively large head (head circumference 54 $\mathrm{cm})$, brachycephaly, oval shaped facies, arched eyebrows, mongoloid slanting eyes, hypertelorism (inner canthal measurement $4 \mathrm{~cm}$, outer canthal measurement $12 \mathrm{~cm}$ ), a prominent nasal bridge, severe kyphoscoliosis, thoracic dysplasia, a ventricular septal defect type murmur over the left precordial area, long thin fingers with clubbing and peripheral cyanosis, bilateral camptodactyly of the fifth fingers, and a valgus deformity of the feet. His heart lesion has not been investigated.

\section{CASE 3}

V.21 is the second child of normal parents. After an uneventful pregnancy, she was born at term by normal vertex delivery; her birth weight is unknown. The father and mother were 34 and 28 years old, respectively, at the time of the birth. As a baby she was hypotonic.

At the age of 13 years she was admitted to a mental institution where she presented with the following clinical features (fig 6): severe mental retardation, a relatively large head, brachycephaly, a large high forehead, long flat facies, fine arched eyebrows, narrow palpebral fissures, a prominent nasal bridge, retrognathia, a high arched palate, large ears, drooping shoulders, scoliosis, thoracic dysplasia, long thin fingers, camptodactyly of the

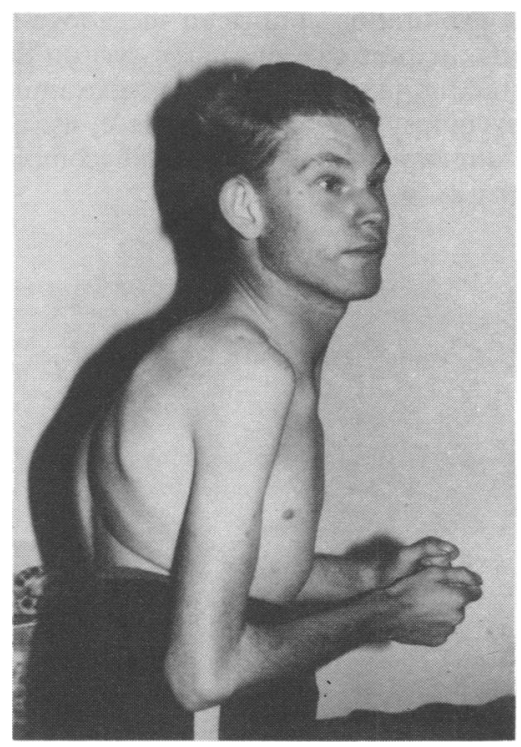

FIG 5 Case $2(V .22)$ at the age of 19 years. 


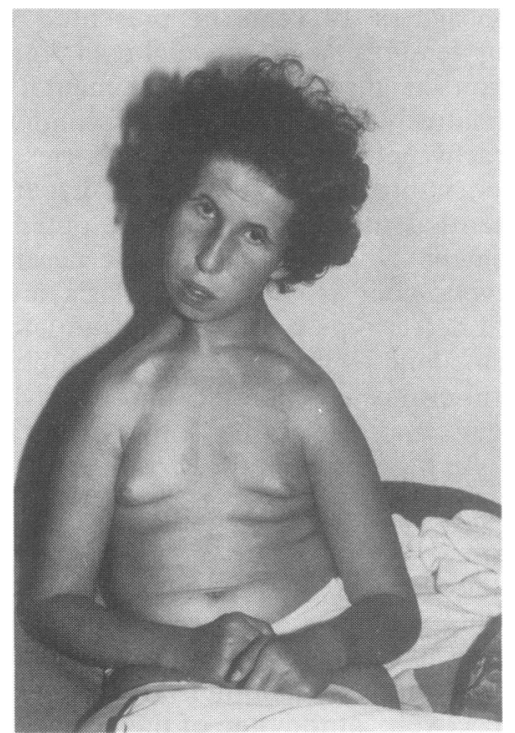

FIG 6 Case $3(V .21)$ at the age of 13 years.

second finger of the right hand and the fifth finger bilaterally, hypoplastic dermal ridges, ulnar deviation of the hands, a valgus deformity of the feet and a wide space between the first and second toes (fig 7).

At the age of 15 years she was investigated for a possible renal mass. A renal angiogram demonstrated a horseshoe shaped kidney with multiple renal arteries supplying both sides of the kidney. Surgical exploration confirmed the above findings, as well as the presence of a large cyst on the upper pole of the right kidney. Histological examination of a kidney biopsy revealed multiple cysts. She died shortly afterwards of postoperative complications. No necropsy. was done.

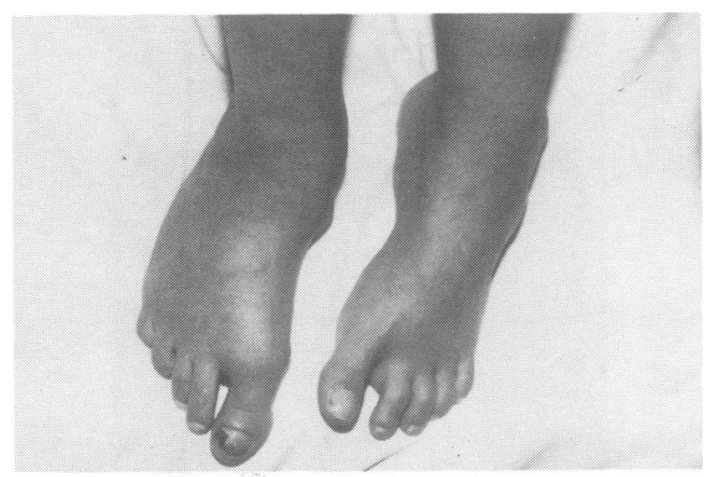

FIG 7 Case 3 (V.21) showing abnormalities of the feet.

\section{CASE 4}

VI.27 is the second child of normal parents. After an uneventful pregnancy he was born at term by forceps delivery; his birth weight was $3200 \mathrm{~g}$. His father and mother were 30 and 24 years old, respectively, at the time of his birth. He presented with an undescended testis on the right side and had surgical repair of two inguinal hernias. He was admitted to a mental institution at the age of 20 months.

When he was evaluated at the age of 15 years, he was still inarticulate. He presented with growth retardation (height $132 \mathrm{~cm}$ ), weight $30 \mathrm{~kg}$, severe mental retardation, a relatively big head (fig 8), brachycephaly, a large high forehead, oval facies, narrow palpebral fissures, bilateral epicanthic folds, mongoloid slanting eyes, hypertelorism (inner canthal measurement $4 \mathrm{~cm}$, outer canthal measurement $12 \mathrm{~cm}$ ), a flat nasal bridge, a short nose, a long philtrum, a bow shaped mouth, a high arched palate, low set ears, a short neck, kyphosis of the lumbar vertebrae, long thin fingers, a simian crease on the right palm, hypoplastic dermal ridges, and overlapping of the second and third toes. A radiological examination of the spine, pelvis, and hands was performed. The lumbar kyphosis was confirmed an\& bilateral coxa valga and a generalised decrease in density were revealed, as well as a delay in skeletat maturation. The pisiform bones were absent bilaterally.

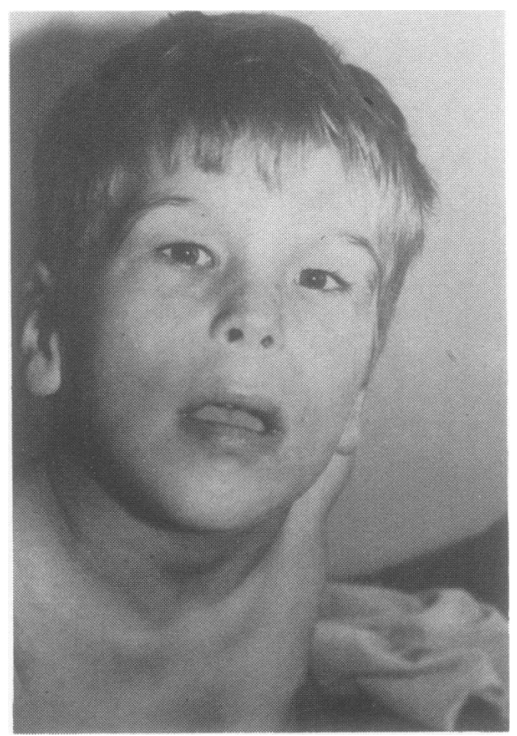

FIG 8 Case 4 (VI.27) at the age of 15 years. 
CASE 5

VI. 3 is the only child of normal parents. After an uneventful pregnancy he was born at term by Caesarian section because of cephalopelvic disproportion; he weighed approximately $4000 \mathrm{~g}$. Both parents were 26 years old at the time of his birth. $\mathrm{He}$ presented as a strange looking baby (fig 9), with hypotonia, brachycephaly, a third fontanelle, narrow palpebral fissures, mongoloid slanting eyes, bilateral epicanthic folds, hypertelorism, a flat nasal bridge, an accessory nipple on the left side of the thorax, a pilonidal sinus, and a systolic heart murmur. On heart catheterisation he was shown to have a preductal aortic coarctation, a ventricular septal defect, and a patent ductus arteriosus. The coarctation was surgically repaired at the age of 4 months.

At the age of 4 years he presented with the following clinical features: weight $15.6 \mathrm{~kg}$, normal length $(99 \mathrm{~cm})$, severe mental retardation, a relatively large head (head circumference $52 \mathrm{~cm}$ ), brachycephaly, a large high forehead, an oval flat facies, narrow palpebral fissures, bilateral epicanthic folds, mongoloid slanting eyes, hypertelorism (inner canthal measurement $4 \mathrm{~cm}$, outer canthal measurement $12 \mathrm{~cm}$ ), a short nose, a long philtrum, a bow shaped mouth, large ears, a short neck, a wide space between the first and second toes, and overlapping of the second and third toes, bilaterally.

CASE 6

VI.39 was a male fetus terminated at 20 weeks' gestation after a partial trisomy $10 \mathrm{q} 25 \cdot 2 \rightarrow$ qter chromosome constitution had been detected in the amniotic fluid. This was the fifth pregnancy of the

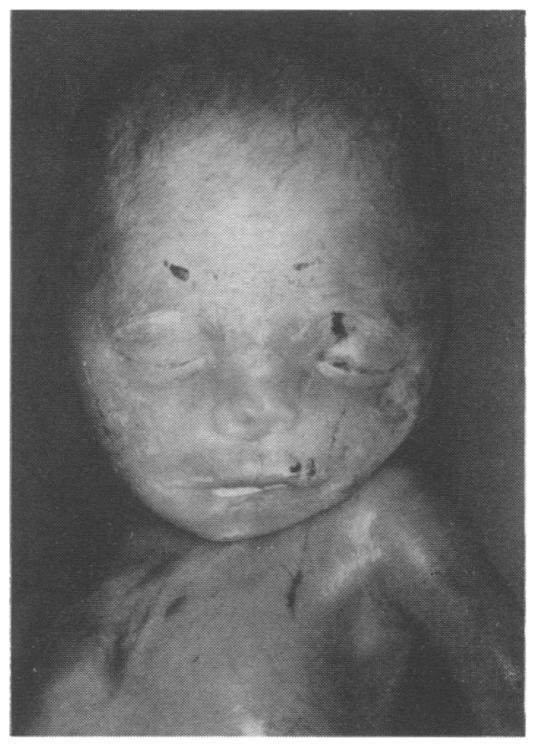

FIG 10 Case 6 (VI.39) at 20 weeks' gestation.

mother of the proband; her third pregnancy had been terminated at 20 weeks' gestation for the same reason.

The fetus (fig 10) presented with a relatively large head, brachycephaly, a large forehead, flat oval facies, antimongoloid slanting eyes, hypertelorism, a flat nasal bridge, a short nose, a long philtrum, micrognathia, and a short neck. No other abnormalities could be detected clinically. No necropsy was performed.

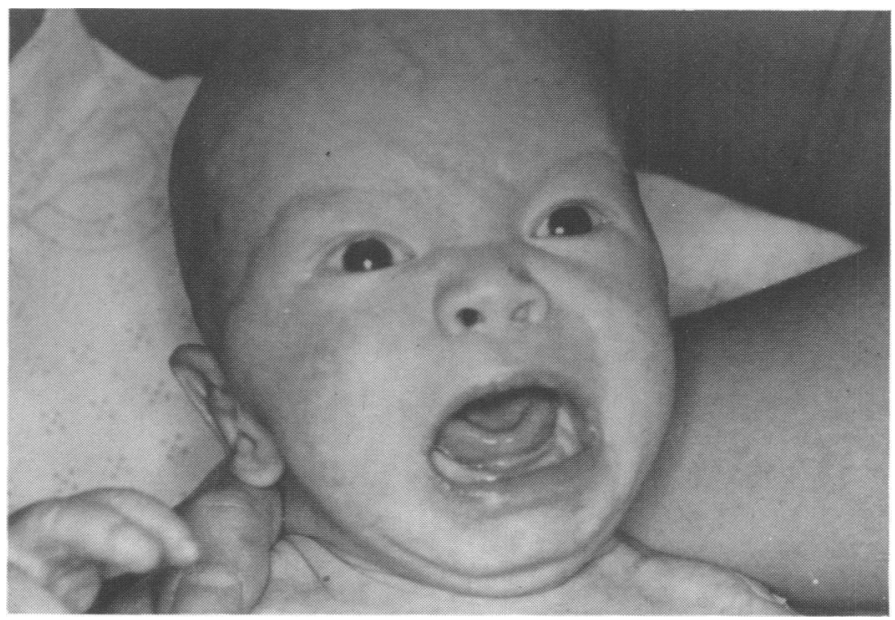

FIG 9 Case 5 (VI.3) at birth. 


\section{Discussion}

Aurias et $a l^{37}$ reported an excess of telomeric breakpoints in all cases of translocations ascertained through offspring with an unbalanced reciprocal translocation, especially in cases of $2: 2$ segregation (as in the present study). They also found an excess of breakpoints in $10 \mathrm{q}$.

Among the phenotypically normal subjects in the present study, there was a fairly equal distribution of balanced carriers and chromosomally normal offspring, as is theoretically expected; a significant excess of balanced carriers has, however, often been reported. ${ }^{38}$

In the present study, an altered sex ratio (three males:two females) was observed among the offspring of both male and female carrier parents. Among the offspring with a partial trisomy $10 \mathrm{q} 25 \cdot 2 \rightarrow \mathrm{qter}$, a very marked sex difference was found (eight males:one female). A preponderance of affected males has previously been reported. ${ }^{15}$ These sex ratios and the occurrence of first trimester miscarriages recorded in the pedigree indicate that certain unbalanced chromosome complements are less compatible with life than others. The single case of partial monosomy $10 \mathrm{q} 25 \cdot 2 \rightarrow \mathrm{qter}$ in this study indicates very strongly the reduced viability of fetuses with this deletion (the proband died 15 days after birth). This factor may contribute significantly to the number of miscarriages recorded. Male fetuses with partial trisomy $10 \mathrm{q} 25 \cdot 2 \rightarrow$ qter appear to have a selective advantage for survival over their female counterparts and the non-viability of female fetuses with this abnormality could account for some of the miscarriages.

Petrosky and Borgaonkar ${ }^{38}$ reviewed 327 pedigrees, including those involving translocations of $6 \mathrm{q}$ and 10q. They recorded a high fetal loss rate for both male and female carriers of $10 \mathrm{q}$ translocations and also for female carriers of $6 \mathrm{q}$ translocations. In addition to the size of the chromosome imbalance produced, loss or duplication of critical loci may be involved in the production of some chromosome complements which are incompatible with fetal survival.

Glutamic oxaloacetic transaminase (the enzyme which catalyses the reversible conversion of aspartate and $\alpha$-ketoglutarate to oxaloacetate and glutamate) plays a significant role in maintaining nitrogen balance in metabolism. By electrophoresis it has been possible to demonstrate two forms of human glutamic oxaloacetic transaminase (GOT), the mitochondrial and the cytoplasmic forms. Creagen et $a l^{39}$ have shown that they are coded for by separate loci. The structural gene coding for cytoplasmic GOT has been assigned to chromosome 10

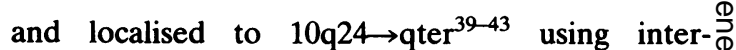
specific somatic cell hybrids and also by gene dosage studies. More recently, this gene has been localised to $10 \mathrm{q} 24 \rightarrow \mathrm{q} 25,{ }^{44} 10 \mathrm{q} 24,{ }^{45} 46$ and $10 \mathrm{q} 26 \cdot 1$ (or 10q25.3). ${ }^{47}$ Similar studies on the affected members $\frac{}{0}$ of this pedigree would help to localise the position of $\frac{\overline{\bar{s}}}{\overline{2}}$ the gene.

Dysmorphic features found in all or most of the $\frac{\varnothing}{\varrho}$ six cases of partial trisomy $10 \mathrm{q} 25 \cdot 2 \rightarrow$ qter pre- $\omega$ sented in table 3 include growth retardation, severe $\vec{\circ}$ mental retardation, a relatively large head, $\vec{\overrightarrow{ }}$ brachycephaly, a large high forehead, narrow

TABLE 3 Comparison of clinical features of present six cases of partial trisomy $10 q 25 \cdot 2 \rightarrow$ qter.

\begin{tabular}{|c|c|c|c|c|c|c|}
\hline Clinical features & $\begin{array}{l}\text { Case } \\
1\end{array}$ & $\begin{array}{l}\text { Case } \\
2\end{array}$ & $\begin{array}{l}\text { Case } \\
3\end{array}$ & $\begin{array}{l}\text { Case } \\
4\end{array}$ & $\begin{array}{l}\text { Case } \\
5\end{array}$ & $\begin{array}{l}\text { Case } \\
6\end{array}$ \\
\hline Mental retardation & + & + & + & + & + & \\
\hline $\begin{array}{l}\text { Aggressive behaviour } \\
\text { Growth retardation: }\end{array}$ & + & & + & & + & \\
\hline Height $<3 \%$ & + & + & & + & - & \\
\hline $\begin{array}{l}\text { Weight }<3 \% \\
\text { Head circumference }\end{array}$ & - & + & - & + & - & \\
\hline$<3 \%$ & - & - & & - & - & \\
\hline Brachycephaly & + & + & + & + & + & $+c$ \\
\hline Large high forehead & + & - & + & + & + & \\
\hline Long facies & + & - & + & - & - & $-\vartheta$ \\
\hline Oval facies & - & + & - & + & + & $+\overline{\bar{n}}$ \\
\hline Flat facies & - & - & + & - & + & $+\frac{c}{9}$ \\
\hline $\begin{array}{l}\text { Fine arched eyebrows } \\
\text { Narrow palpebral }\end{array}$ & - & + & + & - & - & \\
\hline fissures & + & - & + & + & + & - \\
\hline $\begin{array}{l}\text { Epicanthus } \\
\text { Mongoloid slanting }\end{array}$ & - & - & - & + & + & - \\
\hline eyes & + & + & - & + & + & - \\
\hline Hypertelorism & + & + & & + & + & + \\
\hline Prominent nasal bridge & + & + & + & - & - & - \\
\hline Short nose & - & - & - & + & + & - \\
\hline Long philtrum & - & - & - & + & + & + \\
\hline Bow shaped mouth & - & - & - & + & + & - \\
\hline Micro/retrognathia & - & - & + & - & - & + \\
\hline Low set ears & - & - & - & + & - & \\
\hline Big ears & + & - & + & - & + & \\
\hline Short neck & - & - & - & + & + & + \\
\hline Drooping shoulders & + & - & + & - & - & - \\
\hline Kyphoscoliosis & + & + & + & + & - & - \\
\hline Dysplasia of thorax & + & + & + & - & - & - \\
\hline Long thin fingers & + & + & + & + & - & - \\
\hline Camptodactyly & - & + & + & - & - & - \\
\hline Simian crease & - & - & - & + & - & - \\
\hline $\begin{array}{l}\text { Hypoplastic dermal } \\
\text { ridges }\end{array}$ & - & - & + & + & - & - \\
\hline $\begin{array}{l}\text { Increased space } \\
\text { between 1st and } \\
2 \text { nd toes }\end{array}$ & - & - & + & - & + & - \\
\hline Pes planovarus/valgus & + & + & + & - & - & - \\
\hline $\begin{array}{l}\text { Overlapping toes } \\
\text { Congenital heart }\end{array}$ & - & - & - & + & + & - \\
\hline disease & - & + & - & - & + & \\
\hline Renal abnormalities & & & + & & & \\
\hline Hypotonia & & & + & & + & \\
\hline Inguinal hernia & & & & + & & \\
\hline Cryptorchidism & & & & + & & \\
\hline High arched palate & & & + & + & - & \\
\hline Ulnar deviation & & & & & & \\
\hline $\begin{array}{l}\text { of hands } \\
\text { Delayed bone }\end{array}$ & & & + & & & \\
\hline maturation & & & & + & & \\
\hline
\end{tabular}




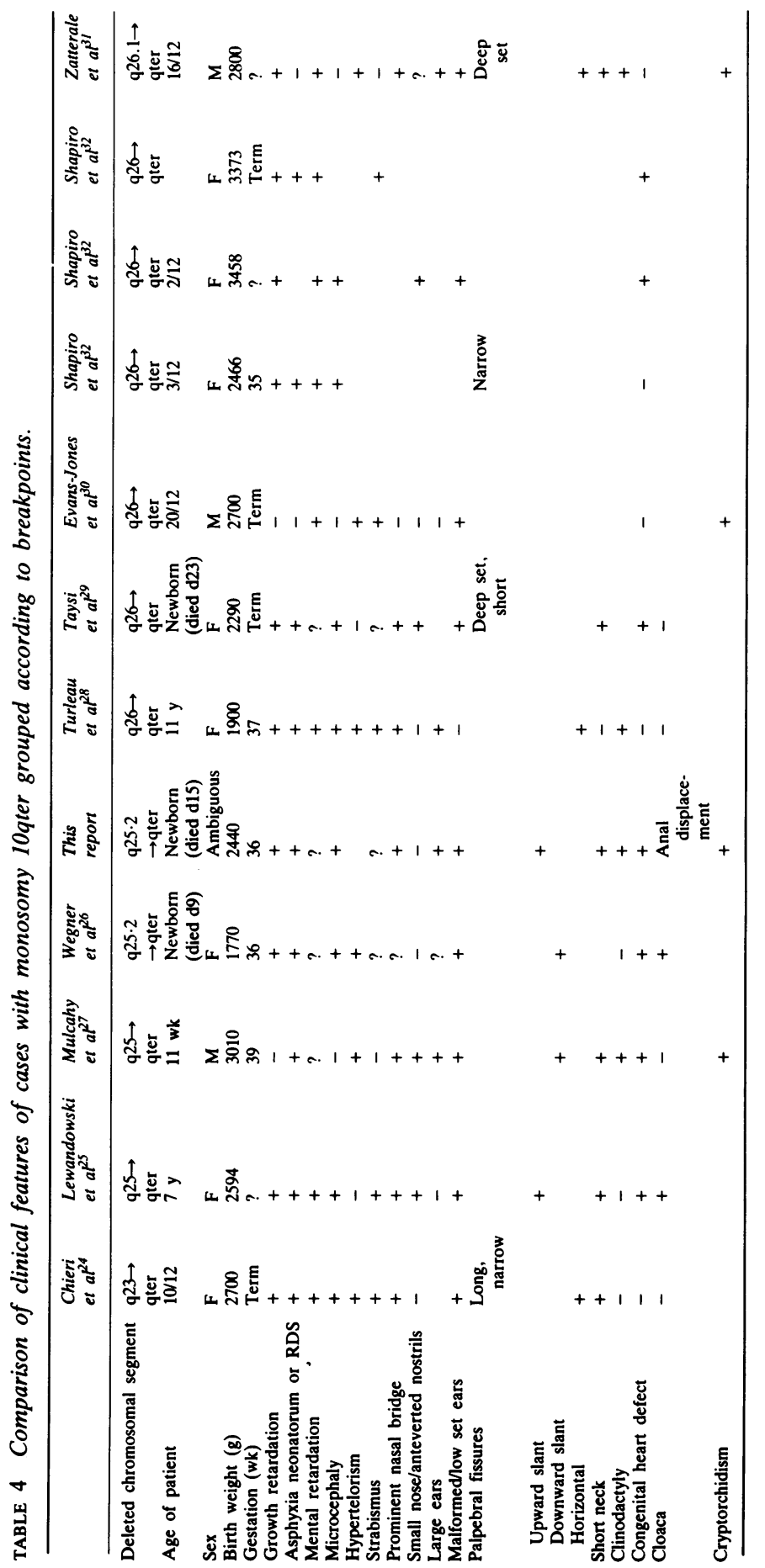


palpebral fissures, mongoloid slanting eyes, hypertelorism, kyphoscoliosis, and long tapering fingers.

The present cases differed from seven reported cases of partial trisomy $10 \mathrm{q} 25 \rightarrow \mathrm{qter}^{17} 2021$ by the absence of microcephaly, microphthalmia, ptosis of the eyelids, cleft palate, and dislocation of the hips.

The present cases differ from the partial trisomy $10 \mathrm{q}$ syndrome, that is, partial trisomy $10 \mathrm{q} 24 \longrightarrow$ qter, ${ }^{22}{ }^{23}$ in that there was a normal birth weight, but absence of microcephaly, microphthalmia, cleft palate, ptosis of the upper eyelids, anteverted nostrils, malformed ears, pectus excavatum, clenched overlapping fingers, and rockerbottom feet. Four of the present cases had mongoloid slanting eyes; antimongoloid slants were found in published reports. Only two of the present cases had clinical heart defects and kidney abnormalities were confirmed in only one case. Additional features found in this group are drooping shoulders (two cases) and progressive deafness (case 1); the latter could not be investigated.

Decreased bone maturation and 11 pairs of ribs are described in the partial trisomy $10 \mathrm{q}$ syndrome, but, unfortunately, all the present cases could not be radiologically investigated. The clinical cyanotic congenital heart lesion of case 2 could not be investigated. No IQ estimations could be done.

Most of the features considered to be characteristic of the partial trisomy $10 \mathrm{q}$ syndrome ${ }^{23}$ appear to be associated with partial trisomy of $10 \mathrm{q} 25 \rightarrow$ qter. A partial trisomy of the region $10 \mathrm{q} 22 \rightarrow \mathrm{q} 24$ may not contribute significantly to the phenotype. ${ }^{1521}$

Variations of certain features between the present familial cases and other published cases may be due to loss of telomeric material on the other chromosome involved in the translocation. ${ }^{9}$ No resemblance could, however, be found between the present six cases and those patients with deletions of the long arm of chromosome $6 .{ }^{48}$ Yunis and Lewandowski ${ }^{15}$ found that there was a general tendency for $10 \mathrm{q}$ to translocate to a telomeric region of another chromosome with minimal or no reciprocal loss of genetic material. This could explain the similarity of persons with the partial trisomy $10 \mathrm{q}$ syndrome and hence aid the clinical diagnosis of this syndrome.

There are nine reports of a partial deletion of the distal part of the long arm of chromosome 10 . The clinical features of these cases are presented in table 4. In four cases, the breakpoint occurred in $10 \mathrm{q} 25$ and asphyxia neonatorum, abnormal palpebral fissures, low set, malformed ears, and a congenital heart defect were present in all. The two female patients had cloaca type defects and the two male patients had cryptorchidism.

Although asphyxia neonatorum, microcephaly, growth retardation, a prominent nasal bridge, and $\frac{\mathbb{\Phi}}{\overparen{D}}$ low set, malformed ears seemed to be the most $\stackrel{\Phi}{\stackrel{\oplus}{?}}$ common abnormalities, more cases need to be $\vec{F}$ described to ascertain whether these features will $\stackrel{\mathcal{O}}{\oplus}$ eventually delineate the partial monosomy $10 \mathrm{q}$ ? syndrome.

\section{Conclusion}

From the pedigree it can be concluded that the fertility of male and female subjects carrying a balanced translocation $t(6 ; 10)$ has not been ad- $\vec{\omega}$ versely affected. There were more phenotypically normal offspring than phenotypically abnormal offspring. In the former group, there were similar i numbers of karyotypically normal subjects and $\omega$ balanced carriers. The most common unbalanced chromosome abnormality among the offspring was found to be partial trisomy $10 \mathrm{q} 25 \cdot 2 \rightarrow \mathrm{qter}$ 을 associated with severe mental retardation; eight of $\stackrel{ }{\supset}$ the nine cases were males. Offspring with partial $O$ monosomy $10 \mathrm{q} 25 \cdot 2 \rightarrow \mathrm{qter}$ did not survive. Spontaneous miscarriages were often recorded. $\frac{0}{0}$ Genetic counselling and the facility of amniocentesis or chorionic villi sampling are of great importance in $\vec{\bullet}$ such pedigrees for the prenatal detection of phengs $\stackrel{\circ}{\circ}$ typically abnormal offspring.

The authors wish to thank the Cape Provincia Administration, the South African Medical Research Council, and the University of Stellenbosch for their support. The secretarial assistance of Mrs $\cong$ Maralin Page is gratefully acknowledged.

\footnotetext{
References

${ }^{1}$ Francke U. Quinacrine mustard fluorescence of human chromosomes: characterization of unusual translocations. Am J Hum Genet 1972;24:189-213.

${ }^{2}$ Laurent C, Bovier-Lapierre M, Dutrillaux B. Trisomie $10{ }^{\circ}$ partielle par translocation familiale $t(1 ; 10)(q 44 ; q 22) . \underline{3}$ Humangenetik 1973;18:321-7.

3 Yunis JJ, Sanchez O. A new syndrome resulting from partial $\delta$ trisomy for the distal third of the long arm of chromosome $10 . J$ Pediatr 1974;84:567-70.

4 Field B, Smith A, Sillence D. Malformation syndrome of chromosome $10 \mathrm{q}$ duplication and the Vater association. Ann $\frac{D}{\mathrm{O}}$ Genet (Paris) 1983;26:31-3.

5 Bass HN, Sparkes RS, Crandall BF, Tannenbaum SM. Familial partial trisomy $10 \mathrm{q}(\mathrm{q} 23 \rightarrow \mathrm{qter})$ syndrome and paracentric inver- $\sigma$ sion 3(q31q26) in the same patient. Ann Genet (Paris) $N$ 1978;21:74-7.

6 Dutrillaux B, Laurent C, Robert JM, Lejeune J. Inversionc péricentrique, inv(10), chez la mère et aneusomie de recom- $O$ binaison, inv(10), rec(10), chez son fils. Cytogenet Cell Genet 1973;12:245-53.

${ }^{7}$ Mulcahy MT, Jenkyn J, Masters PL. A familial 10/13 transloca- $\overline{\mathbb{D}}$ tion: partial trisomy $C$ in an infant associated with familial 10/13 $\stackrel{?}{+}$ translocation. Clin Genet 1974;6:335-40.

8 Roux C, Taillemite JL, Baheux-Morlier G. Trisomie partielle 10q par translocation familiale $\mathrm{t}(10 \mathrm{q}-; 22 \mathrm{p}+)$. Ann Genet $\overrightarrow{\mathbb{D}}$ (Paris) 1974;17:59-62.
} 
${ }^{9}$ Moreno-Fuenmayor H, Zackai EH, Mellman WJ. Aronson M. Familial partial trisomy of the long arm of chromosome 10 (q24-26). Pediatrics 1975;56:756-61.

10 Prieur M, Forabosco A, Dutrillaux B, Laurent C, Bernasconi S, Lejeune J. La trisomie 10q24 10qter. Ann Genet (Paris) 1975;18:217-22.

1 Zackai E, Mellman W. Aronson M, Miller RC. Greene AE, Coriell LL. A $(10 ; 17)$ translocation, unbalanced, 46 chromosomes. Cytogenet Cell Genet 1975;14:90-1.

12 Berger R, Derre J, Murawsky M, Amiel-Tison C. Trisomie 10q partielle de novo. J Genet Hum 1976;24:261-9.

13 Sills JA, Buckton KE, Raeburn JA. Severe mental retardation in a boy with partial trisomy $10 \mathrm{q}$ and partial monosomy $2 \mathrm{q} . J$ Med Genet 1976;13:507-10.

14 Fraisse J, Lauras B, La Selve A, Freycon F. Deux nouveaux cas de trisomie $10 \mathrm{q} 24 \rightarrow 10 \mathrm{qter}$ chez deux soeurs par translocation paternelle t(9;10)(q34;q24). Ann Genet (Paris) 1977;20:128-31.

15 Yunis JJ, Lewandowski C Jr. Partial duplication $10 \mathrm{q}$ and duplication 10p syndromes. In: Yunis JJ, ed. New chromosomal syndromes. New York: Academic Press, 1977:219-44.

16 Back E, Kosmützky K, Schuwald A, Hameister H. Two cases of partial trisomy $10 \mathrm{q}$ in the same family caused by parental direct insertion [ins(15;10)(q15;q24q26)]. Ann Genet (Paris) 1979; 22:195-8.

17 Klep-de Pater JM, Bijlsma JB, de France HF, Leschot NJ, Duijndam-van den Berge $M$, van Hemel JO. Partial trisomy 10q. Hum Genet 1979;46:29-40.

18 Aledo AG, Gracia R, López Pajares I, González M, Oliver A, Peralta A. Trisomía parcial $10 \mathrm{q}(\mathrm{q} 24$; qter) debida a una translocación materna $\mathrm{t}(6 ; 10)(\mathrm{q} 26 ; \mathrm{q} 24)$ balanceada. Esp Pediatr 1982;17:126-9.

19 Van de Vooren MJ, Planteydt HT, Hagemeijer A, PetersSlough MF, Timmerman MJ. Familial balanced insertion $(5 ; 10)$ and monosomy and trisomy $(10)(\mathrm{q} 24 \cdot 2 \rightarrow \mathrm{q} 25 \cdot 3)$. Clin Genet 1984;25:52-8.

${ }^{20}$ Krøyer S, Niebuhr E. Partial trisomy $10 \mathrm{q}$ occurring in a family with a reciprocal translocation $\mathrm{t}(10 ; 18)(\mathrm{q} 25 ; \mathrm{q} 23)$. Ann Genet (Paris) 1975;18:50-5.

21 Miro R, Templado C, Ponsa M, Serradell J, Marina S, Egozcue J. Balanced translocation $(10 ; 13)$ in a father, ascertained through the study of meiosis in semen, and partial trisomy $10 \mathrm{q}$ in his son. Hum Genet 1980;53:179-82.

22 Smith DW. Recognizable patterns of human malformation. 3rd ed. Philadelphia: Saunders, 1982:8.

23 Schinzel A. Catalogue of unbalanced chromosome aberrations in man. Berlin: de Gruyter, 1984.

${ }^{24}$ Chieri P, Iölster N. Monosomy 10qter due to a balanced maternal translocation: $\mathrm{t}(10 ; 8)(\mathrm{q} 23 ; \mathrm{p} 23)$. Clin Genet 1983; 24:147-50.

25 Lewandowski RC Jr, Kukolich MK, Sears JW, Mankinen CB. Partial deletion 10q. Hum Genet 1978;42:339-43.

26 Wegner RD, Kunze J, Paust H. Monosomy 10qter due to a balanced familial translocation: $\mathrm{t}(10 ; 16)(\mathrm{q} 25 \cdot 2 ; \mathrm{q} 24)$. Clin Genet 1981;19:130-3.

${ }^{27}$ Mulcahy MT, Pemberton PJ, Thompson E, Watson M. Is there a monosomy 10qter syndrome? Clin Genet 1982;21:33-5.

28 Turleau C, de Grouchy J, Ponsot G, Bouygues D. Monosomy 10qter. Hum Genet 1979;47:233-7.

29 Taysi K, Strauss AW, Yang V, Padmalatha C, Marshall RE. Terminal deletion of the long arm of chromosome $10 \mathrm{q} 26 \rightarrow \mathrm{qter}$. Ann Genet (Paris) 1982;25:141-4.

30 Evans-Jones G, Walker S, Howard PJ. A further case of monosomy 10qter. Clin Genet 1983;24:216-9.
31 Zatterale A, Pagano L, Fioretti G, et al. Clinical features of monosomy 10qter. Ann Genet (Paris) 1983;26:106-8.

32 Shapiro SD. Hansen KL. Pasztor LM, et al. Deletions of the long arm of chromosome 10. Am J Med Genet 1985;20:181-96.

33 Seabright M. A rapid banding technique for human chromosomes. Lancet 1971;ii:971-2.

34 Caspersson T, Zech L, Johansson C. Differential binding of alkylating fluorochromes in human chromosomes. Exp Cell Res 1970;60:315-9.

35 Paris Conference (1971). Standardization in human cytogenetics. Birth Defects 1972;8(7).

36 ISCN (1981). An international system for human cytogenetic nomenclature: high resolution banding. Cytogenetic Cell Genet 1981:31:1-32.

${ }^{37}$ Aurias A, Prieur M, Dutrillaux B, Lejeune J. Systematic analysis of 95 reciprocal translocations of autosomes. Hum Genet 1978;45:259-82.

38 Petrosky DL, Borgaonkar DS. Segregation analysis in reciprocal translocation carriers. Am J Med Genet 1984;19:137-59.

39 Creagan R, Tischfield J, McMorris FA, et al. Assignment of the genes for human peptidase $A$ to chromosome 18 and cytoplasmic glutamic oxaloacetate transaminase to chromosome 10 using somatic-cell hybrids. Cytogenet Cell Genet 1973;12:187-98.

40 Hellkuhl B, Grzeschik KH. Localization of GOT to the $\mathrm{q} 24 \rightarrow$ qter region of human chromosome 10 . Human Gene Mapping 3, 1975. Cytogenet Cell Genet 1976;16:1-5.

${ }^{41}$ Hellkuhl B, Grzeschik KH. Regional mapping of human chromosome 10: assignment of the gene for cytoplasmic glutamate-oxaloacetate transaminase to $10 \mathrm{q} 24 \rightarrow \mathrm{qter}$. Hum Genet 1976;33:109-12.

42 Chern CJ, Mellman WJ, Croce CM. Localization of the structural locus for cytoplasmic glutamic-oxaloacetic transaminase to region $\mathrm{q} 24 \rightarrow \mathrm{qter}$ of human chromosome 10. Cytogenet Cell Genet 1976;16:1-5.

43 Junien C, Turleau C, Bugnon C, Bresson JL, Roche P, de Grouchy J. Localisation de $\mathrm{TGO}_{\mathrm{S}}$ en $10 \mathrm{q} 24 \mathrm{q} 262$ et suggestion de localisation de HK-1 en 10q23. Ann Genet (Paris) 1979;22:50-2.

44 Aitken DA, Ferguson-Smith MA. Gene dosage evidence for the regional assignment of the GOTs structural gene locus to $10 \mathrm{q} 24 \rightarrow 10 \mathrm{q} 25$. Cytogenet Cell Genet 1978;22:468-71.

45 Gitelman BJ, Tomkins DJ, Partington MW, Roberts MH, Simpson NE. Gene dosage studies of glutamic oxaloacetic transaminase (GOT) and hexokinase (HK) in two patients with possible partial trisomy 10q. Am J Hum Genet 1980;32:41A.

46 Baeteman MA, Mattei MG, Mattei JF, Rebuffel P, Giraud F. Refined mapping of GOT1, PP and HK1 on chromosome 10. Human Gene Mapping 6, Oslo Conference 1981. Cytogenet Cell Genet 1982;32:251A.

47 Junien C, Despoisse S, Turleau C, de Grouchy J, Bucher T, Fundele R. Assignment of phosphoglycerate mutase (PGMA) to human chromosome 10. Regional mapping of GOT1 and PGAMA to subbands 10q26.1 (or q25.3). Ann Genet (Paris) 1982;25:25-7.

48 Young RS, Fidone GS, Reider-Garcia PA, Hansen KL, McCombs JL, Moore CM. Deletions of the long arm of chromosome 6: two new cases and review of the literature. Am J Med Genet 1985;20:21-9.

Correspondence and requests for reprints to $\mathrm{Dr} J$ Brusnický, MRC Research Unit for Cytogenetics, University of Stellenbosch Medical School, PO Box 63, Tygerberg 7505, Republic of South Africa. 